JURNAL KACAPURI

JURNAL KEILMUAN TEKNIK SIPIL

Volume 1 Nomor 2 Edisi Desember 2018

\title{
ANALISIS KINERJA OJEK ONLINE DI KOTA BANJARBARU
}

\author{
${ }^{1)}$ Fiqri Rivaldy Perdana \\ ${ }^{2)}$ Utami Sylvia Lestari \\ ${ }^{1)}$ Teknik Sipil Universitas Lambung Mangkurat Banjarbaru \\ E-mail : aldyperdana96@gmail.com \\ ${ }^{2)}$ Teknik Sipil Universitas Lambung Mangkurat Banjarbaru \\ E-mail : utami.s.lestari@ulm.ac.id
}

\begin{abstract}
ABSTRAK
Kota Banjarbaru adalah salah satu kota besar di provinsi Kalimantan Selatan, dengan kepadatan penduduk terbesar kedua setelah kota Banjarmasin, hal ini membuat pergerakan dan aktivitas warga semakin meningkat, dan membuat masyarakat menggunakan moda transportasi umum, salah satunya adalah ojek. Seiring dengan perkembangan zaman, teknologi, moda transportasi, angkutan umum online menjadi tren di kota Banjarbaru dan sekitarnya, bahkan mulai menggeser angkutan umum konvensional seperti angkot dan ojek konvensional. Objek yang akan diteliti adalah pengguna ojek online di kota Banjarbaru, responden terdiri dari bermacam-macam usia, pekerjaan, dan pendidikan terakhir. Jumlah total sampel pada penelitian ini adalah atau sebanyak 360 responden, yang diperoleh dengan rumus slovin. Untuk mengambil sampel tingkat kinerja. dilakukan survei dengan wawancara dan penyebaran kuesioner kepada pengguna ojek online di Kota Banjarbaru. Sedangkan untuk mengambil sampel tingkat kepentingan, dilakukan survei dengan wawancara dan penyebaran kuesioner kepada stakeholder yang terkait dengan ojek online di Kota Banjarbaru, yakni Samsat Kota Banjarbaru, Kepolisian Lalu Lintas Kota Banjarbaru, dan Dinas Perhubungan Kota Banjarbaru. Kuesioner yang diberikan kepada penguna adalah kuesioner kinerja (performance), sedangkan kuesioner untuk stakeholder adalah kuesioner kepentingan (importance), dengan skala 1 (Sangat tidak baik), 2 (Tidak Baik), 3 (Cukup Baik), 4 (Baik) dan 5 (Sangat Baik). Berdasarkan hasil penelitian dengan metode Importance Performance Analysis, dapat diketahui nilai rata rata tingkat kinerja sebesar 4,20 dan nilai rata rata tingkat kepentingan sebesar 4,59. Sebanyak 3 indikator masuk kuadran 1, sebanyak 6 indikator masuk kuadran II, sebanyak 3 indikator masuk kuadran III, dan sebanyak 2 indikator masuk kuadran IV.
\end{abstract}

Kata Kunci: Ojek Online, Rumus Slovin, Importance Performance Analysis

\begin{abstract}
Banjarbaru is the big cities in the South Kalimantan Province, with the second largest population density after Banjarmasin city, make the movement and activity of
\end{abstract}


citizens more increasing, and make people use public transportation modes, one of them is ojek, Along with the times, technology, and modes of transportation, online public transportation has become a trend Banjarbaru, even starting to replace conventional public transport such as public transportation and conventional ojek. The object to be studied are online ojek users in the city of Banjarbaru, respondents consisting of various ages, occupations, and recent education. Total number of samples in this study is 360 respondents, obtained by Slovin formula. To examine the level of performance. survey conducted by interviewing and distributing questionnaires to online ojek users in Banjarbaru. Whereas to take a sample of importance, a survey was conducted by interviewing and distributing questionnaires to stakeholders related to online ojek in Banjarbaru, namely Banjarbaru City Samsat, Banjarbaru Traffic Police, and Banjarbaru City Transportation Agency. The questionnaire which given to users is a performance questionnaire, while the questionnaire for stakeholders is an importance questionnaire, with a scale of 1 (Very bad), 2 (Not Good), 3 (Good enough), 4 (Good) and 5 (Very good). Based on the results of research, it can be seen that the average value of the performance level is 4.20 and the average value of importance is 4.59 . Three indicators entered quadrant 1 , six indicators entered quadrant II, three indicators entered quadrant III, and two indicators entered quadrant IV.

Keywords: Online ojek, Slovin formula, Importance Performance Analysis

\section{PENDAHULUAN}

Kota Banjarbaru adalah salah satu kota besar di provinsi Kalimantan selatan. Berdasarkan data dari Badan Pusat Statistik hingga 27 Februari 2018, Jumlah penduduk di kota Banjarbaru kurang lebih 199.627 jiwa, dengan kepadatan penduduk 607 jiwa/ $/ \mathrm{km}^{2}$, dengan kepadatan penduduk terbesar kedua setelah kota Banjarmasin, membuat pergerakan dan aktivitas warga semakin meningkat, dan membuat masyarakat menggunakan moda transportasi umum, salah satunya adalah ojek.

Seiring dengan perkembangan zaman, teknologi, dan moda transportasi, angkutan umum online (dalam hal ini ojek online), menjadi tren di kota Banjarbaru dan sekitarnya, bahkan mulai menggeser angkutan umum konvensional seperti angkot dan ojek konvensional. Ojek online, memiliki kelebihan dibandingkan dengan ojek konvensional, seperti tarif yang jelas, mudah dicari (cukup menggunakan smartphone, kita bisa mengontak ojek/angkutan umum online), dan lebih menghemat waktu. Dibandingkan dengan menggunakan ojek konvensional, yang terkadang sulit dicari, negosiasi tarif yang susah, dan harus ke pangkalan ojek konvensional untuk menggunakan jasanya, berbeda dengan ojek online yang bisa dikontak di mana saja, tanpa harus ke pangkalan ojek.

Berdasarkan uraian-uraian di atas, maka diadakan penelitian untuk mengetahui faktor-faktor apa saja yang membuat ojek online di Banjarbaru semakin berkembang 
dan mengetahui bagaimana kinerja ojek online di lapangan, diharapkan penelitian "Analisis Kinerja Ojek Online di Kota Banjarbaru" dapat bermanfaat bagi penyedia jasa ojek online untuk mengetahui hal yang membuat konsumen tertarik untuk menggunakan jasa ojek online, sehingga bisa meningkatkan kinerja mereka. Dan untuk pengguna jasa ojek online agar bisa mengetahui bagaimana kinerja ojek online yang mereka gunakan selama beroperasi.

\section{METODE PENELITIAN}

Metodologi penelitian meliputi tahapan-tahapan sebagai berikut :

\section{Identifikasi Masalah}

Identifikasi masalah dilakukan untuk mengenali masalah di dalam penelitian ini, baik dengan studi literatur, maupun dengan pengamatan ke lapangan.

\section{Studi Pustaka}

Studi Pustaka dilakukan untuk menghimpun informasi dan teori-teori dari referensi-referensi yang berkaitan dengan penelitian.

\section{Pengumpulan data}

Data yang dikumpulkan adalah:

a. Data Primer adalah data survei dari pengemudi dan pengguna ojek online.

b. Data Sekunder adalah data kendaraan, pengemudi ojek, dan pengguna ojek yang didapatkan dari kantor cabang Grab dan Gojek Kalimantan Selatan.

\section{Analisis data}

Data yang dikumpulkan dianalisa dengan cara dihitung skor rata-rata kepentingan dan kinerjanya, selnjutnya dimasukkan ke dalam diagram kartesius yang dibatasi oleh sumbu X (tingkat kepuasan) dan sumbu Y (tingkat kinerja).

\section{Hasil Penelitian}

Hasil penelitian berupa nilai tingkat rata-rata, tingkat kepuasan konsumen berupa indikator yang tercantum dalam keempat kuadran IPA.

Metode dalam penelitian dapat digambarkan pada diagram alir sebagai berikut:

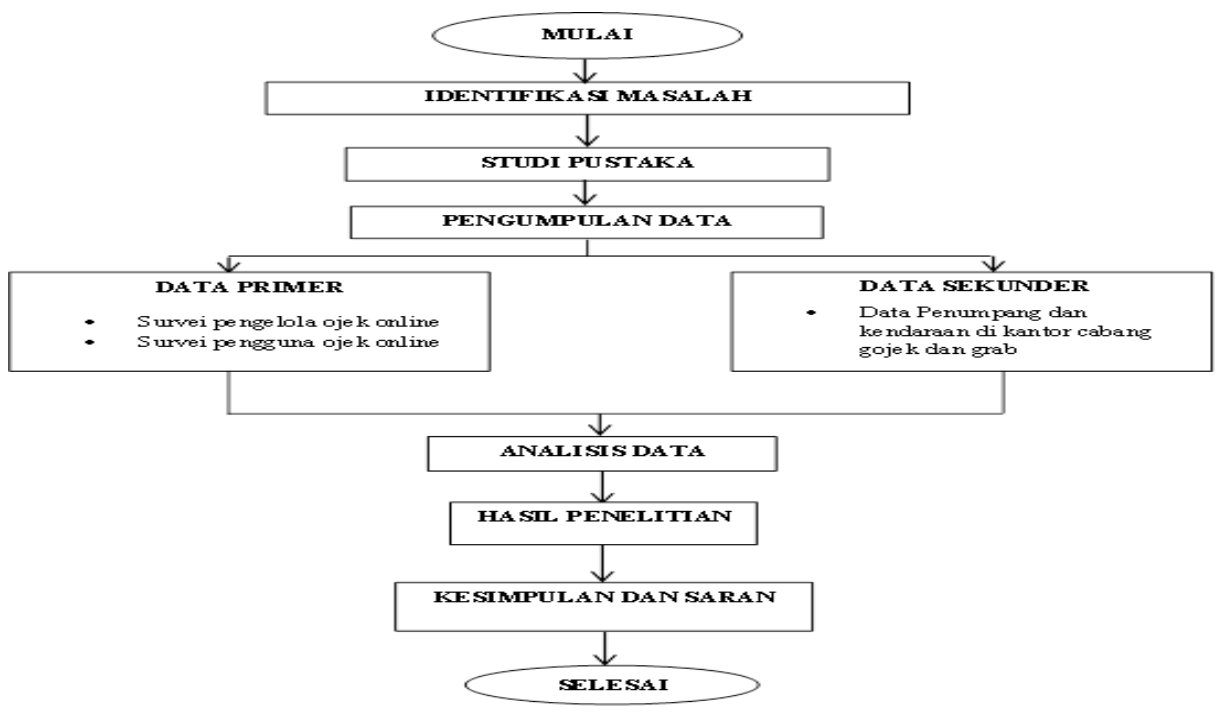




\section{Gambar 1. Diagram Alir Penelitian}

\section{HASIL DAN PEMBAHASAN}

\section{Menentukan Sampel}

Dalam menentukan jumlah sampel objek penelitian, penelitian ini menggunakan rumus slovin, Rumus slovin adalah sebuah rumus untuk menghitung jumlah sampel apabila jumlah populasi tidak diketahui secara pasti., rumus slovin adalah sebagai berikut:

$$
\begin{aligned}
& n=\frac{N}{1+N \cdot e^{2}} \\
& \text { Dimana: } \mathrm{n} \quad=\text { ukuran sampel } \\
& \mathrm{N}=\text { ukuran populasi } \\
& \mathrm{e} \quad=\text { persen kelonggaran ketidaktelitian yang bisa ditolerir }(0,05)
\end{aligned}
$$

Diasumsikan ukuran populasi adalah (jumlah driver gojek dikali rata rata pelanggan per minggu) ditambah dengan (jumlah driver grab dikali rata rata pelanggan per minggu $)$, sehingga didapat ukuran populasi $(300 \times 8)+(100 \times 8)=3200$. Setelah ukuran populasi didapatkan, maka ukuran sampel adalah sebagai berikut:

$n=\frac{3200}{1+3200 \approx 0,05^{2}}=355,56 \approx 360$ buah

Dengan demikian jumlah populasi yang akan disurvei berjumlah 360 buah pelanggan

\section{Karakteristik Responden}

\section{Jumlah Responden Berdasarkan Jenis Kelamin}

Data jenis kelamin responden dari hasil survei melalui kuisioner menunjukan bahwa responden pria sebanyak 175 orang dan responden wanita sebanyak 45 orang. Data selengkapnya dapat dilihat pada tabel 1 berikut.

Tabel 1. Data Responden Berdasarkan Jenis Kelamin

\begin{tabular}{|c|c|c|}
\hline No & Jenis Kelamin & Jumlah Responden \\
\hline 1 & Laki-Laki & 224 \\
\hline 2 & Perempuan & 136 \\
\hline \multicolumn{2}{|c|}{ Total } & $\mathbf{3 6 0}$ \\
\hline
\end{tabular}

Sumber: Hasil Survei

\section{Jumlah Responden Berdasarkan Umur Responden}

Data umur responden dari hasil survei melalui kuisioner menunjukan bahwa responden berusia 13 tahun sampai 65 tahun, dengan responden yang paling banyak 
yaitu kelompok umur 21 tahun sampai 30 tahun sebanyak 164 responden atau 46 persen. Data selengkapnya dapat dilihat pada Tabel 2.

Tabel 2. Data Responden Berdasarkan Umur

\begin{tabular}{|c|c|c|}
\hline No & Kelompok Umur & Jumlah \\
\hline 1 & $\leq 20$ tahun & 33 \\
\hline 2 & $21-30$ tahun & 164 \\
\hline 3 & $31-40$ tahun & 80 \\
\hline 4 & $41-50$ tahun & 54 \\
\hline 5 & $>50$ tahun & 29 \\
\hline \multicolumn{2}{|c|}{ Total } & $\mathbf{3 6 0}$ \\
\hline
\end{tabular}

Sumber: Hasil Survei

\section{Jumlah Responden berdasarkan pendidikan terakhir responden}

Data pendidikan terakhir responden dari hasil survei melalui kuisioner menunjukan bahwa responden dengan pendidikan terakhir paling banyak yaitu SMA sederajat sebanyak 157 orang. Data selengkapnya dapat dilihat pada Tabel 3.

Tabel 3. Data Responden Berdasarkan Pendidikan Terakhir

\begin{tabular}{|c|c|c|}
\hline No & Pendidikan Terakhir & Jumlah Responden \\
\hline 1 & Tidak Sekolah & 0 \\
\hline 2 & SD & 8 \\
\hline 3 & SMP & 12 \\
\hline 4 & SMA & 204 \\
\hline 5 & Perguruan Tinggi & 136 \\
\hline \multicolumn{2}{|c|}{ Total } & $\mathbf{3 6 0}$ \\
\hline
\end{tabular}

Sumber: Hasil Survei

\section{Karakteristik Pengelola}

\section{Jumlah Pengelola Berdasarkan Jenis Kelamin}

Data jenis kelamin Pengelola dari hasil survei melalui kuisioner menunjukan bahwa responden pria sebanyak 256 orang dan responden wanita sebanyak 104 orang. Data selengkapnya dapat dilihat pada Tabel 4.

Tabel 4. Jumlah Responden Pengelola Berdasarkan Jenis Kelamin

\begin{tabular}{|c|c|c|}
\hline No & Jenis Kelamin & Jumlah Responden \\
\hline 1 & Laki-Laki & 256 \\
\hline 2 & Perempuan & 104 \\
\hline \multicolumn{2}{|c|}{ Total } & $\mathbf{3 6 0}$ \\
\hline
\end{tabular}

Sumber: Hasil Survei 
JURNAL KACAPURI

JURNAL KEILMUAN TEKNIK SIPIL

Volume 1 Nomor 2 Edisi Desember 2018

\section{Jumlah Responden Pengelola Berdasarkan Umur}

Data Jumlah Responden Pengelola menunjukkan bahwa pengelola berusia 21 - 30 tahun berjumlah 44 buah, pengelola berusia 31 - 40 tahun berjumlah 119 orang, pengelola berusia 41 - 50 tahun berjumlah 136 orang, dan pengelola berusia $>50$ tahun berjumlah 61 orang, data selengkapnya dapat dilihat pada Tabel 5 .

Tabel 5. Jumlah Responden Pengelola Berdasarkan Umur

\begin{tabular}{|c|c|c|}
\hline No & Kelompok Umur & Jumlah \\
\hline 1 & $21-30$ tahun & 44 \\
\hline 2 & $31-40$ tahun & 119 \\
\hline 3 & $41-50$ tahun & 136 \\
\hline 4 & $>50$ tahun & 61 \\
\hline \multicolumn{2}{|c|}{ Total } & $\mathbf{3 6 0}$ \\
\hline
\end{tabular}

Sumber: Hasil Survei

\section{Jumlah Responden Pengelola Berdasarkan Pendidikan Terakhir}

Data Jumlah Responden Pengelola menunjukkan bahwa pengelola dengan pendidikan terakhir SMA sebanyak 176 buah dan pengelola dengan pendidikan terakhir Perguruan Tinggi sebanyak 184 orang. Data selengkapnya dilihat Tabel 6.

Tabel 6. Jumlah Responden Pengelola Berdasarkan Pendidikan Terakhir

\begin{tabular}{|c|c|c|}
\hline No & Pendidikan Terakhir & Jumlah Responden \\
\hline 1 & SMA & 176 \\
\hline 2 & Perguruan Tinggi & 184 \\
\hline \multicolumn{2}{|c|}{ Total } & $\mathbf{3 6 0}$ \\
\hline
\end{tabular}

Sumber: Hasil Survei

\section{Jumlah Responden Pengelola Berdasarkan Instansi}

Data Jumlah Responden Pengelola menunjukkan bahwa pengelola yang berasal dari Satlantas Polres Banjarbaru sebanyak 130 orang, Pengelola dari Samsat Banjarbaru sebanyak 118 orang. Dan Pengelola dari Dishub Banjarbaru sebanyak 112 orang. Data selengkapnya dapat dilihat pada tabel 7 berikut

Tabel 7. Jumlah Responden Pengelola Berdasarkan Instansi

\begin{tabular}{|c|l|c|}
\hline No & \multicolumn{1}{|c|}{ Jabatan } & Jumlah \\
\hline 1 & Polantas Polres Banjarbaru & 130 \\
\hline 2 & Samsat Banjarbaru & 118 \\
\hline 3 & Dishub Banjarbaru & 112 \\
\hline \multicolumn{2}{|c|}{ Total } & 360 \\
\hline
\end{tabular}

Sumber: Hasil Survei

\section{Importance Performance Analysis}


Mencari Total Skor dalam menentukan total skor yaitu dengan cara menjumlah total responden yang mereka berikan terhadap suatu pelayanan dikali dengan nilai yang telah responden tersebut berikan. Rumus yang digunnakan dalam menentukan total skor adalah sebagai berikut:

Total skor indikator $=\left(1 \times n_{1}\right)+\left(2 \times n_{2}\right)+\left(3 \times n_{3}\right)+\left(4 \times n_{4}\right)+\left(5 \times n_{5}\right)$

Dimana:

$\mathrm{n}_{1}=$ jumlah responden yang memilih nomor 1

$\mathrm{n}_{2}=$ jumlah responden yang memilih nomor 2

$\mathrm{n}_{3}=$ jumlah responden yang memilih nomor 3

$\mathrm{n}_{4}=$ jumlah responden yang memilih nomor 4

$\mathrm{n}_{5}=$ jumlah responden yang memilih nomor 5

Perhitungan skor tingkat kinerja bisa dilihat pada Tabel 7 dan Tabel 8 sbb :

Tabel 7. Tabel Skor Tingkat Kinerja

\begin{tabular}{|c|c|c|c|c|c|c|c|c|}
\hline \multirow[b]{2}{*}{ No } & \multirow[b]{2}{*}{ Indikator } & \multicolumn{7}{|c|}{ Kinerja } \\
\hline & & $\mathbf{1}$ & 2 & 3 & 4 & 5 & $\begin{array}{c}\text { Total } \\
\text { Responden }\end{array}$ & $\begin{array}{l}\text { Total } \\
\text { Skor }\end{array}$ \\
\hline 1 & $\begin{array}{l}\text { Pengemudi memiliki SIM dan } \\
\text { STNK }\end{array}$ & 0 & 0 & 40 & 72 & 248 & 360 & 1648 \\
\hline 2 & Pengemudi memakai helm SNI & 0 & 0 & 24 & 64 & 272 & 360 & 1688 \\
\hline 3 & Identitas pengemudi jelas & 0 & 0 & 32 & 144 & 184 & 360 & 1592 \\
\hline 4 & $\begin{array}{l}\text { Pengemudi sehat secara fisik dan } \\
\text { mental }\end{array}$ & 0 & 0 & 64 & 198 & 98 & 360 & 1474 \\
\hline 5 & $\begin{array}{l}\text { Pengemudi mematuhi peraturan } \\
\text { lalu lintas selama berkendara }\end{array}$ & 0 & 0 & 56 & 96 & 208 & 360 & 1592 \\
\hline 6 & $\begin{array}{l}\text { Kendaraan tidak mengalami } \\
\text { masalah saat beroperasi }\end{array}$ & 0 & 0 & 50 & 141 & 169 & 360 & 1559 \\
\hline 7 & $\begin{array}{l}\text { Tersedianya helm, masker, jas } \\
\text { hujan, penutup kepala }\end{array}$ & 8 & 72 & 104 & 88 & 88 & 360 & 1256 \\
\hline 8 & $\begin{array}{l}\text { Biaya lebih murah daripada } \\
\text { transportasi lainnya }\end{array}$ & 0 & 7 & 118 & 136 & 99 & 360 & 1407 \\
\hline 9 & Pengemudi memiliki sikap ramah & 0 & 0 & 39 & 151 & 170 & 360 & 1571 \\
\hline
\end{tabular}


JURNAL KACAPURI

JURNAL KEILMUAN TEKNIK SIPIL

Volume 1 Nomor 2 Edisi Desember 2018

\begin{tabular}{|c|c|c|c|c|c|c|c|c|}
\hline \multirow[b]{2}{*}{ No } & \multirow[b]{2}{*}{ Indikator } & \multicolumn{7}{|c|}{ Kinerja } \\
\hline & & 1 & 2 & 3 & 4 & 5 & $\begin{array}{c}\text { Total } \\
\text { Responden }\end{array}$ & $\begin{array}{l}\text { Total } \\
\text { Skor }\end{array}$ \\
\hline & dan bersahabat & & & & & & & \\
\hline 10 & $\begin{array}{l}\text { Kendaraan memiliki spion, lampu } \\
\text { depan, dan lampu sen yang layak }\end{array}$ & 0 & 0 & 8 & 128 & 224 & 360 & 1656 \\
\hline 11 & $\begin{array}{l}\text { Aplikasi mudah digunakan dan } \\
\text { memiliki banyak layanan }\end{array}$ & 0 & 16 & 132 & 121 & 91 & 360 & 1367 \\
\hline 12 & $\begin{array}{l}\text { Tersedia layanan pengaduan } \\
\text { penumpang }\end{array}$ & 0 & 2 & 115 & 159 & 84 & 360 & 1405 \\
\hline 13 & Tersedia layanan asuransi & 5 & 43 & 143 & 66 & 103 & 360 & 1299 \\
\hline 14 & $\begin{array}{l}\text { Pemesanan layanan hanya melalui } \\
\text { aplikasi }\end{array}$ & 3 & 20 & 26 & 144 & 167 & 360 & 1532 \\
\hline 15 & $\begin{array}{l}\text { Jumlah penumpang sesuai } \\
\text { kapasitas angkut }\end{array}$ & 8 & 8 & 8 & 96 & 240 & 360 & 1632 \\
\hline
\end{tabular}

\section{Sumber: Hasil Survei}

Tabel 8. Tabel Skor Tingkat Kepentingan

\begin{tabular}{|c|c|c|c|c|c|c|c|c|}
\hline \multirow[b]{2}{*}{ NO } & \multirow[b]{2}{*}{ Indikator } & \multicolumn{7}{|c|}{ Kinerja } \\
\hline & & 1 & 2 & 3 & 4 & 5 & $\begin{array}{c}\text { Total } \\
\text { Responden }\end{array}$ & $\begin{array}{l}\text { Total } \\
\text { Skor }\end{array}$ \\
\hline 1 & $\begin{array}{l}\text { Pengemudi memiliki SIM dan } \\
\text { STNK }\end{array}$ & 0 & 0 & 0 & 24 & 336 & 360 & 1776 \\
\hline 2 & Pengemudi memakai helm SNI & 0 & 6 & 1 & 63 & 290 & 360 & 1717 \\
\hline 3 & Identitas pengemudi jelas & 0 & 0 & 0 & 61 & 299 & 360 & 1739 \\
\hline 4 & $\begin{array}{l}\text { Pengemudi sehat secara fisik dan } \\
\text { mental }\end{array}$ & 0 & 0 & 8 & 34 & 318 & 360 & 1750 \\
\hline 5 & $\begin{array}{l}\text { Pengemudi mematuhi peraturan } \\
\text { lalu lintas selama berkendara }\end{array}$ & 0 & 0 & 1 & 40 & 319 & 360 & 1758 \\
\hline 6 & $\begin{array}{l}\text { Kendaraan tidak mengalami } \\
\text { masalah saat beroperasi }\end{array}$ & 0 & 0 & 19 & 89 & 252 & 360 & 1673 \\
\hline 7 & $\begin{array}{l}\text { Tersedianya helm, masker, jas } \\
\text { hujan, penutup kepala }\end{array}$ & 0 & 0 & 19 & 79 & 262 & 360 & 1683 \\
\hline 8 & $\begin{array}{l}\text { Biaya lebih murah daripada } \\
\text { transportasi lainnya }\end{array}$ & 0 & 1 & 44 & 153 & 162 & 360 & 1556 \\
\hline
\end{tabular}


JURNAL KACAPURI

JURNAL KEILMUAN TEKNIK SIPIL

Volume 1 Nomor 2 Edisi Desember 2018

\begin{tabular}{|c|c|c|c|c|c|c|c|c|}
\hline \multirow[b]{2}{*}{ NO } & \multirow[b]{2}{*}{ Indikator } & \multicolumn{7}{|c|}{ Kinerja } \\
\hline & & 1 & 2 & 3 & 4 & 5 & $\begin{array}{c}\text { Total } \\
\text { Responden }\end{array}$ & $\begin{array}{l}\text { Total } \\
\text { Skor }\end{array}$ \\
\hline 9 & $\begin{array}{l}\text { Pengemudi memiliki sikap ramah } \\
\text { dan bersahabat }\end{array}$ & 0 & 0 & 41 & 132 & 187 & 360 & 1586 \\
\hline 10 & $\begin{array}{l}\text { Kendaraan memiliki spion, lampu } \\
\text { depan, dan lampu sen yang layak }\end{array}$ & 0 & 0 & 9 & 55 & 296 & 360 & 1727 \\
\hline 11 & $\begin{array}{l}\text { Aplikasi mudah digunakan dan } \\
\text { memiliki banyak layanan }\end{array}$ & 0 & 0 & 9 & 113 & 238 & 360 & 1669 \\
\hline 12 & $\begin{array}{l}\text { Tersedia layanan pengaduan } \\
\text { penumpang }\end{array}$ & 0 & 0 & 85 & 177 & 98 & 360 & 1453 \\
\hline 13 & Tersedia layanan asuransi & 0 & 17 & 77 & 122 & 144 & 360 & 1473 \\
\hline 14 & $\begin{array}{l}\text { Pemesanan layanan hanya melalui } \\
\text { aplikasi }\end{array}$ & 0 & 25 & 24 & 137 & 174 & 360 & 1540 \\
\hline 15 & $\begin{array}{l}\text { Jumlah penumpang sesuai } \\
\text { kapasitas angkut }\end{array}$ & 0 & 7 & 8 & 78 & 267 & 360 & 1685 \\
\hline
\end{tabular}

Sumber: Hasil Survei

\section{Analisa Kuadran}

Analisa kuadran dengan SPSS berguna untuk mengetahui kinerja dari atribut-atribut pada penelitian ini, langkah awal dari analisa kuadran adalah mencari skor tingkat kepentingan dan kinerja, rumus mencari skor tingkat kepentingan dan kinerja adalah sebagai berikut:

$$
\overline{\mathrm{X}}=\frac{X i}{n} \quad \overline{\mathrm{Y}}=\frac{Y_{i}}{n}
$$

Dimana:

$\bar{X}=$ Skor tingkat kinerja atribut ke I

$\mathrm{X}_{\mathrm{i}}=$ Skor kinerja atribut ke-i

$\overline{\mathrm{Y}}=$ Skor tingkat kepentingan atribut ke-i

$\mathrm{Y}_{\mathrm{i}}=$ Skor kepentingan atribut ke-i

Perhitungan tabel kuadran IPA dapat dilihat pada Tabel 9. 
JURNAL KACAPURI

JURNAL KEILMUAN TEKNIK SIPIL

Volume 1 Nomor 2 Edisi Desember 2018

Tabel 9. Perhitungan Kuadran IPA

\begin{tabular}{|c|c|c|c|c|c|}
\hline No & Indikator & Skor Kinerja & $\begin{array}{l}\text { Tingkat } \\
\text { Kinerja }\end{array}$ & $\begin{array}{c}\text { Skor } \\
\text { Kepentingan }\end{array}$ & $\begin{array}{c}\text { Tingkat } \\
\text { Kepentingan }\end{array}$ \\
\hline 1 & $\begin{array}{l}\text { Pengemudi memiliki SIM dan } \\
\text { STNK }\end{array}$ & 1648 & 4,58 & 1776 & 4,93 \\
\hline 2 & Pengemudi memakai helm SNI & 1688 & 4,69 & 1717 & 4,77 \\
\hline 3 & Identitas pengemudi jelas & 1592 & 4,42 & 1739 & 4,83 \\
\hline 4 & $\begin{array}{l}\text { Pengemudi sehat secara fisik } \\
\text { dan mental }\end{array}$ & 1474 & 4,09 & 1750 & 4,86 \\
\hline 5 & $\begin{array}{l}\text { Pengemudi mematuhi peraturan } \\
\text { lalu lintas selama berkendara }\end{array}$ & 1592 & 4,42 & 1758 & 4,88 \\
\hline 6 & $\begin{array}{l}\text { Kendaraan tidak mengalami } \\
\text { masalah saat beroperasi }\end{array}$ & 1559 & 4,33 & 1673 & 4,65 \\
\hline 7 & $\begin{array}{l}\text { Tersedianya helm, masker, jas } \\
\text { hujan, penutup kepala }\end{array}$ & 1256 & 3,49 & 1683 & 4,68 \\
\hline 8 & $\begin{array}{l}\text { Biaya lebih murah daripada } \\
\text { transportasi lainnya }\end{array}$ & 1407 & 3,91 & 1556 & 4,32 \\
\hline 9 & $\begin{array}{l}\text { Pengemudi memiliki sikap } \\
\text { ramah dan bersahabat }\end{array}$ & 1571 & 4,36 & 1586 & 4,41 \\
\hline 10 & $\begin{array}{l}\text { Kendaraan memiliki spion, } \\
\text { lampu depan, dan lampu sen } \\
\text { yang layak }\end{array}$ & 1656 & 4,60 & 1727 & 4,80 \\
\hline 11 & $\begin{array}{l}\text { Aplikasi mudah digunakan dan } \\
\text { memiliki banyak layanan }\end{array}$ & 1367 & 3,80 & 1669 & 4,64 \\
\hline 12 & $\begin{array}{l}\text { Tersedia Layanan pengaduan } \\
\text { Penumpang }\end{array}$ & 1405 & 3,90 & 1453 & 4,04 \\
\hline 13 & Tersedia Layanan Asuransi & 1299 & 3,61 & 1473 & 4,09 \\
\hline 14 & $\begin{array}{l}\text { Pemesanan layanan hanya } \\
\text { melalui aplikasi }\end{array}$ & 1532 & 4,26 & 1540 & 4,28 \\
\hline 15 & $\begin{array}{l}\text { Jumlah penumpang sesuai } \\
\text { kapasitas angkut }\end{array}$ & 1632 & 4,53 & 1685 & 4,68 \\
\hline \multicolumn{2}{|c|}{ Total } & 22678 & 4,20 & 24785 & 4,59 \\
\hline
\end{tabular}

Sumber: Hasil Perhitungan

\section{Diagram Kartesius}

Setelah menginput nilai rata-rata kepentingan dan kinerja dari tabel 9 ke dalam aplikasi SPSS, lalu dilanjutkan mengolah diagram kartesius. Diawali dengan memilih scatter/dot dengan simple scatter nya, dilanjutkan memilih Y sebagai Importance dan 
JURNAL KACAPURI

JURNAL KEILMUAN TEKNIK SIPIL

Volume 1 Nomor 2 Edisi Desember 2018

$\mathrm{X}$ sebagai Performance serta nomor sebagai label cases nya. Nomor ini berguna untuk memperjelas atribut-atribut pelayanaan pada diagram kartesius. Nilai rata-rata tingkat kinerja $(\overline{\bar{X}}=4,19)$ dan tingkat kepentingan $(\overline{\bar{Y}}=4,56)$ menentukan letak garis untuk membagi diagram kartesius menjadi empat kuadran. Hasil diagram kartesius dapat dilihat pada Gambar 2 sebagai berikut :

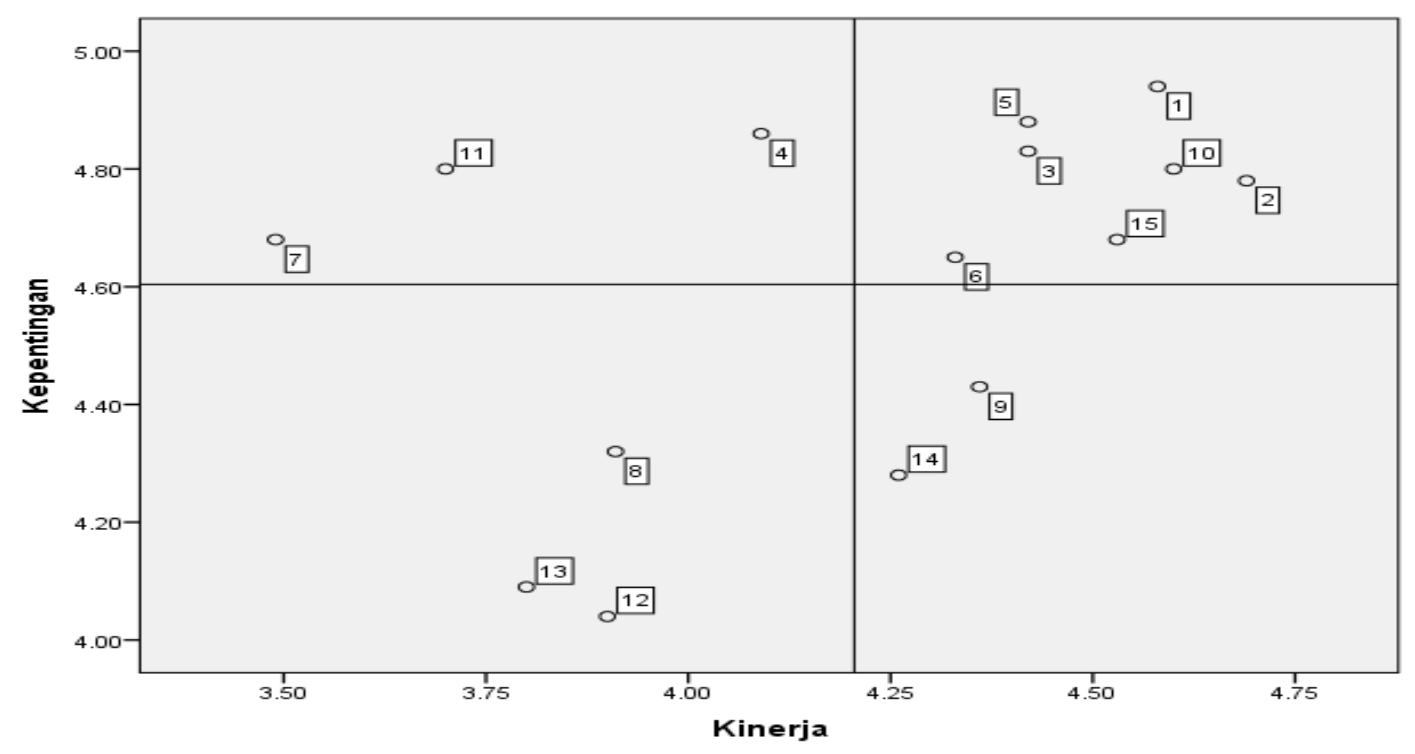

Gambar 2. Diagram Kartesius

Ringkasan Kuadran IPA dapat dilihat pada Tabel 10 sebagai berikut :

Tabel 10. Ringkasan Kuadran IPA

\begin{tabular}{|c|c|}
\hline \multirow{3}{*}{ Kuadran I (Prioritas Utama) } & Pengemudi sehat secara fisik dan mental \\
\hline & Tersedianya helm, masker, jas hujan, penutup kepala \\
\hline & Aplikasi mudah digunakan dan memiliki banyak layanan \\
\hline \multirow{7}{*}{ Kuadran II (Pertahankan) } & Pengemudi memiliki SIM dan STNK \\
\hline & Pengemudi memakai helm SNI \\
\hline & Identitas pengemudi jelas \\
\hline & Pengemudi mematuhi peraturan lalu lintas selama berkendara \\
\hline & $\begin{array}{l}\text { Kendaraan memiliki spion, lampu depan, dan lampu sen yang } \\
\text { layak }\end{array}$ \\
\hline & Jumlah penumpang sesuai kapasitas angkut \\
\hline & Kendaraan tidak mengalami masalah saat beroperasi \\
\hline \multirow{3}{*}{ Kuadran III (Prioritas Rendah) } & Tersedia layanan pengaduan penumpang \\
\hline & Tersedia layanan asuransi \\
\hline & Biaya lebih murah daripada transportasi lainnya \\
\hline
\end{tabular}


JURNAL KACAPURI

JURNAL KEILMUAN TEKNIK SIPIL

Volume 1 Nomor 2 Edisi Desember 2018

\begin{tabular}{|l|l|}
\multirow{2}{*}{ Kuadran IV (Berlebihan) } & Pemesanan layanan hanya melalui aplikasi \\
\cline { 2 - 2 } & Pengemudi memiliki sikap ramah dan bersahabat \\
\hline
\end{tabular}

Sumber: Hasil Perhitungan

Berdasarkan ringkasan kuadran diagram kartesius pada tabel 10, tabel tersebut terdiri dari empat kuadran yang masing-masing menjelaskan keadaan yang berbeda. Pada kuadran I terdapat tiga jenis indikator yang dianggap penting oleh penggguna ojek online , tetapi tingkat kinerjanya masih belum sesuai harapan.

Pada kuadran II terdapat tujuh jenis pelayanan yang dianggap penting oleh penggguna dan sudah sesuai sehingga tingkat kepuasannya relatif lebih tinggi. Ketujuh jenis pelayanan ini harus dipertahankan atau bahkan ditingkatkan lagi kinerjanya.

Pada kuadran III terdapat tiga jenis indikator yang dianggap kurang penting oleh pengguna dan kinerja Indikator tersebut kurang baik. Sehingga peningkatan indikator yang termasuk ke kuadran ini perlu dipertimbangkan walaupun tidak begitu dianggap penting oleh pengguna.

Pada kuadran IV terdapat dua Indikator yang dianggap kurang penting bagi pengguna, tetapi memiliki kinerja yang bagus, sehingga dianggap berlebihan. Harus dilakukan efisiensi pada indikator ini, untuk menghemat biaya

\section{PENUTUP}

\section{Kesimpulan}

Kesimpulan dari penelitian ini adalah sebagai berikut:

1. Ojek online adalah salah satu moda transportasi yang diminati semua kalangan, terbukti dari responden yang berasal dari beragam umur dan pendidikan terakhir

2. Dari penelitian ini, dapat diketahui nilai rata-rata kinerja menurut penumpang adalah 4,419, sedangkan nilai rata-rata kepentingan menurut stakeholder adalah 4,482

3. Beberapa aspek di ojek online penting bagi pengguna, tetapi kinerja belum memenuh harapan pengguna, yaitu Pengemudi sehat secara fisik dan mental, Tersedianya helm, masker, jas hujan, penutup kepala, dan Aplikasi mudah digunakan dan memiliki banyak layanan.

4. Beberapa aspek di ojek online memiliki kinerja yang baik dan dianggap penting, antara lain: Pengemudi memiliki SIM dan STNK, Pengemudi memakai helm SNI Identitas pengemudi jelas, Pengemudi sehat secara fisik dan mental, Pengemudi mematuhi peraturan lalu lintas selama berkendara, Kendaraan tidak mengalami masalah saat beroperasi, Kendaraan memiliki spion, lampu depan, dan lampu sen yang layak, Aplikasi mudah digunakan dan memiliki banyak layanan, dan Jumlah penumpang sesuai kapasitas angkut

5. Beberapa aspek di ojek online memiliki kinerja yang kurang bagus dan tidak terlalu penting untuk konsumen, yaitu: Tersedianya helm, masker, jas hujan, penutup kepala Biaya lebih murah daripada transportasi lainnya, Pengemudi 
JURNAL KACAPURI

JURNAL KEILMUAN TEKNIK SIPIL

Volume 1 Nomor 2 Edisi Desember 2018

memiliki sikap ramah dan bersahabat, Tersedia Layanan pengaduan Penumpang, Tersedia Layanan Asuransi, dan Pemesanan layanan hanya melalui aplikasi

6. Beberapa aspek di ojek online kinerjanya baik, tetapi tidak terlalu penting, yaitu: Kendaraan tidak mengalami masalah saat beroperasi dan Pengemudi memiliki sikap ramah dan bersahabat

\section{Saran-saran}

Saran yang dapat diberikan dari penelitian ini adalah sebagai berikut:

1. Pertanyaan harus mudah dimengerti oleh pengguna ojek online, karena pengguna ojek online berasal dari berbagai latar belakang pendidikan dan usia

2. Hasil dari penelitian ini bisa menjadi pertimbangan untuk penyedia jasa ojek online untuk meningkatkan pelayanan kepada penumpang ojek online di kota Banjarbaru, terutama meningkatkan indikator indikator yang kurang optimal

\section{DAFTAR PUSTAKA}

Bahri, Syaiful. 2004. Penilaian Variabel Kepuasan Karyawan Menggunakan Metode Analisis Kepentingan dan Analisis Kuadran (Studi Kasus Karyawan PDAM Kota Kandangan). Jurnal Info Teknik Volume 5 No 2, Desember 2004, 89-95

Brandt, D.R., 2000. An “Outside-In” Approach to Determining Customer Driven Priorities for Improvement and Innovation. White Paper Series. Volume 2.

KBBI. (2018). Arti Kata Ojek. https://www.kbbi.web.id/ojek. Diakses pada Rabu, 4 Juli 2018

Kotler, Philip, 1994. Marketing Management: Analysis, Planing, Implementation \& Control. Prentice Hall International Edition. Eight Edition

Kotler, Philip. 2008. Manajemen Pemasaran Edisi 12 Jilid 2. Jakarta: Indeks

Republik Indonesia. 2009. Undang-undang No 22 tahun 2009 tentang Lalu Lintas dan Angkutan Jalan. Jakarta: Sekretariat Negara.

Rozi, Fakhrul, SH. (2017). Pengertian Ojek Online. https://www.suduthukum.com/2017/03/ojek-online.html. Diakses pada Rabu, 4 Juli 2018

Supranto. 2006. Pengukuran Tingkat Kepuasan Pelanggan. Jakarta: Rineka Cipta

Umar, Husein. 2004. Metode Penelitian untuk Skripsi dan Tesis Bisnis. Cetakan ke-6. Jakarta: PT Raja Grafindo Persada

Wikipedia (2018). Ojek. https://id.wikipedia.org/wiki/Ojek. Diakses pada Rabu, 4 Juli 2018 